\title{
Sistem Pengelolaan Daya Tarik Wisata Pulau Gili Ketapang Sebagai Aset Desa Gili Ketapang, Kecamatan Sumber Asih, Kabupaten Probolinggo
}

Decky Abdi Dermawana, 1 , I Putu Anom a2

1decky.abdi00@gmail.com,2putuanom@unud.ac.id

a Program Studi Sarjana Destinasi Pariwisata, Fakultas Pariwisata, Universitas Udayana, Jl. Dr. R. Goris, Denpasar, Bali 80232 Indonesia

\begin{abstract}
Probolinggo is an area East Java which has beautiful tourism area, especially Gili Ketapang Island. This research purposes to know how the management system in Gili Ketapang Village Asset, Sumber Asih, Probolinggo Regency. The tourist attraction management system is an important indicator in determining the success of a tourist attraction, therefore the attraction of Gili Ketapang requires a good management system in order to become a leading attraction. Data collection techniques conducted in this study are observation techniques, unstructured interview techniques and documentary techniques. Determination technique of informant by using purposive sampling technique. Data analysis technique used is qualitative data.

The conclusion of the discussion is the management system of Gili Ketapang tourist attraction on planning, organizing, actuating, and controlling, in each of the five components there are variables of tourism attraction, management and improvement of human resources, tourism facilities, service quality improvement, and promotion and marketing.On the other hand, this study also discusses what obstacles faced by government and society in the implementation of Gili Ketapang tourism management system.In knowing these obstacles required variables are physical constraints, among others, regarding parking, access, lodging, and shopping. Non-physical constraints on the social condition of the community, the condition of human resources, economic benefits, and institutions. Suggestions are addressed to the next Government, Manager, Society, and Academia in subsequent research
\end{abstract}

\section{Keywords: Management system, Tourist Attraction, and constraints.}

\section{PENDAHULUAN}

Indonesia merupakan sebuah negara kepulauan yang memiliki banyak potensi sumberdaya alam yang melimpah dan beranekaragam pula etnik budaya daerah yang khas, sehingga sangat mendukung pengembangan sektor strategis nasional yaitu pariwisata. Begitu pula pembangunan pariwisata di Provinsi Jawa Timur juga sangat potensial dalam meningkatkan Pendapatan Asli Daerah (PAD) jika dikembangkan dengan baik. Melalui implementasi Undang-Undang Nomor 12 Tahun 2008 tentang Pemerintah Daerah telah memberikan peluang bagi Pemerintah Daerah untuk mengelola dan mengoptimalkan potensi daerahnya secara mandiri temasuk mengelola sektor pariwisata. Upaya pembangunan pariwisata di Provinsi Jawa Timur ini ditunjukan oleh Dinas Kebudayaaan dan Pariwisata Jawa Timur dengan membuat sebuah program "Visit East Java" pada tahun 2011, yang bertujuan untuk menarik wisatawan dengan memperkenalkan kepada dunia bahwa Jawa Timur memiliki berbagai kekayaan alam dan budaya yang sangat istemewa sehingga menarik untuk dikunjungi. Dalam program Visit East Java ini, wisata pulau Gili Ketapang Kabupaten Probolinggo ditunjuk sebagai salah satu destinasi unggulan pariwisata di Jawa Timur. Kabupaten Probolinggo yang mempunyai destinasi wisata yang menarik akan anda jumpai di Jawa Timur, tepatnya di Kabupaten Probolinggo ini merupakan kota terbesar ke-4 se-Jawa Timur dilihat dari jumlah penduduknya. Kota ini terkenal dengan Kabupaten/Kota Mangga dan Anggur, Kota Seribu Taman, karena kota yang hijau dan bersih. Probolinggo adalah Kabupaten/Kota dengan banyak destinasi wisata yang indah dan menarik untuk di kunjungi. Daya tari wisata yang indah dan menarik untuk dikunjungi antara lain adalah Gunung Bromo, Pantai Bentar, Madakaripura waterfall, Danau Ranu Agung, Arun Jeram Rafting, dan yang saat ini sedang popular dikunjungi oleh pemudapemudi serta keluarga adalah wisata Gili Ketang, sebagai wisata bahari dan keindahan alam bawah lautnya.

Pada rangka mengangkat Kabupaten Probolinggo sebagai wisata bahari yang sangat populer dengan potensi yang ada di daya tarik wisata Pulau Gili Ketapang. Pemerintah Daerah Kabupaten Probolinggo menyiapkan programprogram pengembangan pariwisata. Upaya promosi wisata mengakibatkan beberapa tahun terakhir pariwisata di Kabupaten Probolinggo 
berkembang pesat. Hal ini dilihat dari munculnya tempat wisata-wisata konvensional baru, salah satunya daya tarik wisata Pulau Gilli Ketapang. Pantai yang indah dengan pemandangan alam yang mempesona, terumbu karang yang cantik dan banyak jenis ikan yang cantik yang bisa ditemui, selain itu juga bisa atraksi snorkling di tempat ini. Namun, perkembangan pariwisata di Kabupaten Probolinggo memunculkan permasalahan baru yaitu pembangunan pariwisata tidak lagi memperhatikan kondisi lingkungan yang selaras dengan pembangunan ekonomi, adanya beberapa keganjalan dalam sistem pengelolaan daya tarik wisata contohnya seperti adanya penduduk asing yang membuka jasa pariwisata di daya tarik wisata Gili Ketapang, padahal sudah ditetapkan peratuan bahwa yang diizinkan untuk beropasi atau yang menjadi aset desa adalah masyarakat lokal, selain itu masyarakat lokal belom berpartisipasi secara maksimal dalam pembangunan pariwisata, masyarakat yang masih enggan menerima wisatawan asing dan masih banyak lagi kendala sistem pengelolaan yang ada di daya tarik wisata pulau Gili Ketapang.

Sebagai tujuan Destinasi Wisata Jawa Timur, Kabupaten Probolinggo notabene adalah mengedepankan potensi alamnya yang indah dan sejuk. Oleh karena itu, dalam penanganan masalah pengelolaan daya tarik wisata pulau Gili Ketapang Probolinggo, perlu adanya upaya dalam menangani pembangunan pariwisata yang bertujuan untuk meningkatkan perekonomian dan melestarikan lingkungan perlu disertai upaya memperhatikan aspek lingkungan dan keikut sertaan masyarakat dalam pengelolaan daya tarik tersebut, agar tidak ada yang dirugikan dalam pembangunan pariwisata ini baik itu masyarakat, budaya dan alam. Penelitian ini bertujuan untuk menetahui sistem pengelolaan daya tarik wisata atau sumberdaya alam dan budaya tanpa merusak konsep ekologis dari lingkungan wisata itu sendiri dan juga dapat memajukan potensi pariwisata lokal sebagai aset desa Gili Ketapang. Sistem pengelolaan pulau Gili Ketapang, desa Ketapang mengusung konsep tradisional dengan melibatkan masyarakat lokal untuk berpartisipasi langsung sebagai manajemen pengelola. Dalam hal ini aktor utama dalam sistem pengelolaan daya tarik wisata pulau Gili Ketapang ini sepenuhnya adalah masyarakat lokal.

\section{KEPUSTAKAAN}

\subsection{Tinjauan Penelitian sebelumnya}

Telaah penelitian sebelumnya sangat penting dilakukan yang berguna untuk mendapatkan perbandingan antara penelitian yang saat ini dilakukan dengan penelitian sebelumnya yang telah dilakukan oleh peneliti lain. Selain itu, peneliti juga dapat mengetahui posisi penelitiannya dari perbandingan dengan penelitian lain dari segi fokus rumusan masalah pada penelitian. Terdapat beberapa penelitian sebelumnya yang digunakan untuk memposisikan penelitian yang akan dilakukan berdasarkan fokus (topik penelitian) dan locus penelitian (lokasi penelitian).

Penelitian ini mengunakan dua hasil penelitian sebagai referensi. Hasil penelitian yang dilakukan oleh I Nyoman Widiarta (2016) yang berjudul "Pengelolaan Daya Tarik Wisata Pura Taman Ayun Sebagai Bagian Dari Warisan Budaya Dunia". Adapun relevansi dari jurnal tersebut dengan penelitian ini ialah fokus dari penelitian tersebut, dimana membahas tentang pengelolaan Daya Tarik Wisata. Referensi skripsi kedua yaitu ditulis oleh Zainur Rofiq (2013) yang berjudul tentang Nilai Sosial dan Ekonomi pada Tradisi Ngalak Anak di Pulau Gili Ketapang, Kabupaten Probolinggo. Kesamaan skripsi tersebut dengan penelitian ini yaitu membahas tentang lokasi yang sama yaitu Pulau Gili Ketapang, Probolinggo.

\subsection{Landasan Konsep.}

Penelitian ini mengunakan tiga konsep untuk menganalisis permasalahan dalam tulisan ini yaitu konsep pengelolaan, konsep ini berfungsi sebagai mendiskripsikan pekerjaan Manajer berdasarkan fungsinya yakni perencanaan (Planning), pengorganisasian (Organizing), penggerakkan (Actuating), 
pengendalian (Controlling) (Siswanto, 2005 : 18). Dalam penelitian ini, konsep pengelolaan akan menjawab permasalahan tentang pengelolaan Daya Tarik Wisata Pulau Gili Ketapang. Konsep yang kedua adalah konsep Daya Tarik Wisata menurut Yoeti (2006:167) untuk menganalisis dan mengidentifikasi daya Tarik berdasarkan natural attraction, build attraction, cultural attraction, dan social attraction. Konsep terakhir adalah konsep fasilitas pariwisata menurut Yoeti (1990: 81) yang berfungsi untuk menganalisis sarana (sarana pokok, sarana pelangkap, sarana penunjang ) dan prasarana ( Prasarana umum dan Prasarana yang menyangkut ketertiban dan keamanan ).

\section{METODE PENELITIAN}

Penelitian ini berlokasi di Desa Gili Ketapang, Kecamatan Sumber Asih, Kabupaten Probolinggo yang merupakan sebuah pulau kecil yang memiliki luas sekitar 68 ha dan jumlah penduduk sekitar 7.600 jiwa.. Jenis data yang digunakan didalam penelitian ini terdiri atas dua jenis data, yakni Data Kualitatif dan Data Kuantitatif (Bungin dan Sugiyono, 2003). Sumber data yang digunakan dalam penelitian ini adalah sunber data primer (Moleong, 2000) dan data sekunder (Sugiyono, 2008). Data primer dalam penelitian ini diantaranya adalah gambaran umum permasalahan Pengelolaan Daya Tarik Wisata Pulau Gili Ketapang sebagai Aset Masyarakat Desa Gili Ketapang, Probolinggo. Data Sekunder dalam penelitian ini berupa profil Desa Gili Ketapang seperti letak geografis, data monografi dan data kunjungan. Teknik pengumpulan data dalam penelitian ini ialah dengan teknik observasi (Akbar dan Usman, 2009), wawancara mendalam (Menurut Satori dan Komariyah, 2010) dengan para informan dan dokumentasi (Indrawan dan Yaniawati, 2014).

Teknik analisis data dalam penelitian ini mengunakan teknik analisis deskriptif kualitatif (Sugiyono, 2014). Teknik analisis deskriptif memiliki empat langkah yaitu pertama tahap pengumpulan data dimana peneliti dalam tahap ini mengumpulkan data sesuai dengan keadaan di lapangan, selanjutnya yaitu reduksi data, dimana data yang sudah di dapatkan dan di kumpulkan di pilah ataupun di filter sesuai kebutuhan penelitian, data tersebut adalah mengenai data gambaran umum Pulau Gili Ketapangfasilitas pariwisata, pengelolaan Daya Tarik Wisata, tingkat kunjungan Wisata Pulau Gili Ketapang, selanjutnya yaitu penyajiian data yang dilakukan dengan menyajikan data yang telah direduksi seperti hasil wawancara dalam bentuk naratif, dan yang terakhir adalah kesimpulan, dalam peneIitian ini data yang diperoleh akan diverifikasi dan ditarik kesimpulan sesuai dengan topik permasalahan sehingga dapat menghasilkan data aktual dan di uji kevaliditasannya mengenai Sistem Pengelolaan Daya Tarik Wisata Pulau Gili Ketapang, Probolinggo.

\section{HASIL DAN PEMBAHASAN}

\subsection{Sistem Pengelolaan Daya Tarik Wisata Pulau Gili Ketapang}

Sistem pengelolaan Daya Tarik Wisata Pulau Gili Ketapang dari diresmikankan pulau tersebut menjadi suatu Kawasan pariwisata telah mendapatkan suatu pujian dan juga komentar dari sebagian wisatawan. Secara administratif, pulau ini masih termasuk dalam Kabupaten Probolinggo. Untuk lokasi tepatnya wisata ini berada di Desa Gili Ketapang, Kecamatan Sumber Asih, Probolinggo, Provinsi Jawa Timur. Sedangkan untuk rute penyeberangan dimulai dari pelabuhan Tanjung Tembaga. Lama waktu penyeberangan ini kurang lebih memakan 30 menit. Pulau ini memiliki luas sekitar 61.000 hektar. Desa Gili Ketapang merupakan desa yang cukup banyak memiliki penduduk 8.424 jiwa dengan luas wilayah 0,61 km2 sehingga dapat mencapai kepadatan penduduk kurang lebih 13.809,84 jiwa.

Daya Tarik Wisata Pulau Gili Ketapang salah satu pulau yang ada di Kabupaten 
Probolinggo yang dikelola oleh masyarakat lokal. Berdasarkan penelitian yang dilakukan oleh peneliti di lapangan, ada beberapa sistem pengelolaan yang dapat dilakukan oleh Pihak Pengelola bersama masyarakat lokal yaitu sebagai berikut:

\subsubsection{Perencanaan (Planning)}

Perencanaan adalah pemilihan atau penetapan tujuan organisasi dan penentuan strategi, kebijakan, proyek, program, prosedur, metode, sistem, anggaran dan standar yang dibutuhkan untuk mencapai tujuan.

" Di tahun 2019 akan ada banyak pembaharuan di sini mas, ada beberapa perencanaan yang sudah disusun oleh pengelola sini contohnya seperti perbaikan fasilitas, promosi, atraksi, dan tingkat pengelolaannya juga mas." (Hasil wawancana, 25 April 2018).

(1) Perencanaan atraksi yang akan diadakan di daya tarik wisata Pulau Gili Ketapang ialah akan diadakan atraksi diving di zona laut pulau Gili Ketapang, pelestarian terumbu karang dan ikan akan dikembangkan semaksimal mungkin, dan akan ada penyewaan sepeda pancal dan jalur jalan untuk sepeda pancal mengeliling pulau Gili Ketapang. (2) Perencanaan Pengelola dan Peningkatan SDM akan melaksanakan kegiatan pembinaan dan pelatihan kepada staff, pihak pengelola masing-masing zona dan masyarakat sekitar dalam menjaga dan mengembangkan daya tarik wisata Pulau Gili Ketapang, agar tetap pada komitmen awal yang telah dirancang dan disepakati bersama. Selain itu perencanaan pengelola dan Peningkatan SDM akan melaksanakan pemberian pelatihan dalam pembuatan sovenir lokal atau oleh-oleh khas dari Daya tarik wisata Gili Ketapang yang akan diproduksi oleh masyarakat lokal. (3)Perencanaan fasilitas pariwisata di Gili Ketapang akan dibangun toilet yang lebih produktif dan efisien dalam pembuangan air bekas dan kualitas toilet baik bagi wisatawan khususnya wisatawan domestik dan wisatawan asing. Selain itu akan ada perbaikan toilet yang lebih baik dan mewah untuk wisatawan.
" Fasilitas toilet dari dulu ya seperti ini mas, tidak ada perubahan meskipun sudah banyak ada komen dari wisatawan terhadap fasilitas toilet yang masih kurang bagus, masih baru wacana perbaikan toilet ini mas, semoga saja segera diperbaiki" (Hasil wawancana, 25 April 2018). (4) Perencanaan peningkatan kualitas layanan yang akan dilakukan di daya tarik wisata Gili Ketapang ialah tentang hospitality yang baik, meningkatkan kualitas kebersihan dan kenyamana wisatawan, serta akan mengadakan reward gift kepada staff terbaik di setiap bulannya. (5) Perencanaan Pemerintah dan Pengelola akan melakukan kegiatan promosi dan pemasaran Daya Tarik Wisata Pulau Gili Ketapang besar-besaran melalui media cetak dan elektronik, serta media online seiring kemajuan perkembangan teknologi dan informasi.

\subsubsection{Pengorganisasian (Organizing)}

Proses pengorganisasian yaitu bagaimana suatu perencanaan yang sudah dibuat dalam pengelolaan Daya Tarik Wisata Pulau Gili Ketapang bisa tercapai tapat sasaran. Adapun proses pengorganisasian yang dilakukan pengelola terkait atraksi wisata di Daya Tarik Wisata Gili Ketapang sebagai berikut:

(1) Pengelola membuat dan mengatur jadwal atraksi wisata snorkling. (2) Pengelola membuat dan mengatur jadwal penjemputan dan pengantaran wisatawan, dan Pengelola membuat papan pengumuman yang berisi aturan-aturan dari Pemerintah, kepala Desa terkait pelestarian ekosistem laut dan potensi alam, serta lingkungan. (3) Pengorganisasian dalam Pengelolaan dan Peningkatan Sumber Daya Manusia antara lain adalah Pengelola membuat dan mengatur jadwal pembinaan setta pelatihan bagi pengelola masing-masing zona beserta staffnya dan masyarakat, selain itu pembuatan sovenir yang dilakukan oleh pengelola dan masyarakat desa. (5)Pengorganisasian dalam fasilitas bariwisata antara lain adala pengelola menyediakan dan menata tempat dan sumber daya manusia 
yang akan merawat secara berkelanjutan dan membenahi kekurangan yang ada pada daya tarik wisata Gili Ketapang sehingga terciptanya kenyamanan dan keharmonisan. (6)Pengorganisasian dalam peningkatan kualitas layanan antara lain adalah pengelola membuat aturan mengenai penggunaan pakaian seragam guna menambah kesan yang baik kepada wisatawan, membuat dan mengatur jadwal kebersihan untuk kenyamanan wisatawan, dan Pengelola membuat dan mengatur jadwal pembinaan bagi pengelola masing-masing zona beserta staffnya dan masyarakat yang terlibat dalam pengelolaan Daya Tarik Wisata Gili Ketapang. (7) Pengorganisasian dalam promosi dan pemasaran antara lain adalah Sumber daya manusia dalam hal mempromosikan dan memasarkan daya tarik wisata Pulau Gili Ketapang yaitu melalui media sosial, seperti facebook, instagram, youtube, koran, dan interaksi.

\subsubsection{Penggerakan Orang-orang (Actuating)}

Dalam hal ini bagaimana proses kerja atau upaya yang dilakukan oleh pihak pengelola alam mengelola Daya Tarik Wisata Gili Ketapang agar semua yang telah direncanakan dapat berjalan dengan baik. Berdasarkan hasil observasi dan wawancara, tindakan-tindakan yang dilakukan pihak pengelola Daya Tarik Wisata Gili Ketapang adalah sebagai berikut. "Semua pekerja di sini merupakan masyarakat Desa Gili Ketapang ini mas, jadi tidak mungkin orang dari desa lainnya", (Hasil wawancara, 25 April 2018).

(1) Penggerak dalam atraksi antara lain adalah Pengelola melaksanakan kegiatan atraksi sesuai dengan apa yang sudah diatur dan telah direncanakan bersama staf dan permintan wisatawan, Pengelola menyediakan usaha jasa foto yang kreatif dan inovatif untuk berfoto di atraksi snorkling dan bisa juga buat video. Selain itu ada juga staf atau petugas yang bertugas mengantarkan wisatawan ke daya tarik wisata Goa Kucing yang berada di sebelah timur desa Gili Ketapang. (2) Penggerak dalam pengelolaan dan peningkatan SDM. (3)Pengelola melaksanakan kegiatan pembinaan bagi pengelola masing-masing zona beserta staffnya dan masyarakat yang terlibat. (4)Penggerak dalam fasilitas pariwisata antara lain adalah Pengelola melaksanakan bersinergi dengan semua masyarakat, beserta staff nya dalam mewujudkan pariwisata yang lebih baik dalam segi fasilitas dan pengelola melaksanakan kerjasana dengan pelabuhan pelindo dalam hal tenaga kerja parkir.(5) Penggerak dalam peningkatan kualitas pelayanan antara lain adalah pengelola telah membuat beberapa seragam guna menunjukkan kerapian dan kesan yang baik kepada wisatawan, selain itu Pengelola memberikan pengarahan kepada pekerja atau staff untuk menggunakan hospitality yang baik. (6) Penggerak dalam promosi dan pemasaran antara lain adalah Pengelola melaksanakan kegiatan promosi dan pemasaran melalui media cetak dan media elektronik serta media sosial.

\subsubsection{Pengawasan (Controlling)}

Demi kelancaran jalannya program dan memastikan perencanaan yang dibuat pihak pengelola dilaksanakan proses pengawasan, selain itu mengevaluasi hasil kerja dari pengelola masing-masing zona dan karyawan apakah sudah menjalankan tugas dengan baik dan sesuai target atau kurang baik.

"Semua pengawasan di sini dilakukan oleh pengelola dan masyarakat mas, jadi kita langsung evaluasi kalua ada kekeliruan dalam menjalankan tugas dan bekerja sebagaimana mestinya". (Hasil wawancara,25 April 2018)

(1) Pengawasan dalam atraksi antara lain adalah Pengelola berkoordinasi dengan Kepala desa yang dalam hal pariwisata sekaligus sebagai Kelompok Sadar Wisata (Pokdarwis) melakukan pengawasan dan evaluasi terhadap pelaksanaan kegiatan atraksi khususnya kegiatan Snorkling. Selain itu pengelola juga melakukan pengawasan di daerah lautan menjaga biota laut.(2) Pengawasan dalam pengelolaan dan peningkatan SDM antara lain adalah Pengelola berkoordinasi dengan Kepala 
Desa dalam melakukan pengawasan dan evaluasi terhadap kegiatan pelatihan yang dilaksanakan dan juga melakukan evalusi terkait kenyamanan wisatawan dalam berkunjung serta staff.(3) Pengawasan dalam fasilitas pariwisata antara lain adalah pengelola berkoordinasi dengan kepada Desa untuk mengadakan pengawasan dan keperihatian terhadap fasilitas semua yang ada di daya tarik wisata Gili Ketapang dan Pengelola berkoordinasi dengan staff dan masyarakat lokal untuk menyediakan tempat samapah, agar terciptanya kebersihan lingkungan. (4)Pengawasan dalam peningkatan kualitas layanan antara lain adalah Pengelola bersnergi dengan kepala desa dan staff untuk mengadakan pengawasan dan evaluasi terhadap penggunaan seragam untuk staff yang telah disepakati bersama. Selain itu Pengelola bersinegi dengan kepala desa mengadakan pengawasandan evaluasi terhadap kegiatan pembinaan mengenai informasi update yang dilaksanakan terhadap pengelola masing-masing zona dan masyarakat sekitar. (5) Pengawasan dalam promosi dan pemasaran antara lain adalah pengelola bersinergi dengan kepala desa mengadakan pengawasan dan evaluasi terhadap kegiatan promosi dan pemasaran yang sedang dan telah dilaksanakan. Di samping itu pengelola bersinergi dengan kepala desa mengadakan pengawasan dan evaluasi terhadap pembuatan brosur dan alat promosi pemasaran lainnya mengenai informasi Daya Tarik Wisata Gili Ketapang yang sudah disepakati bersama.

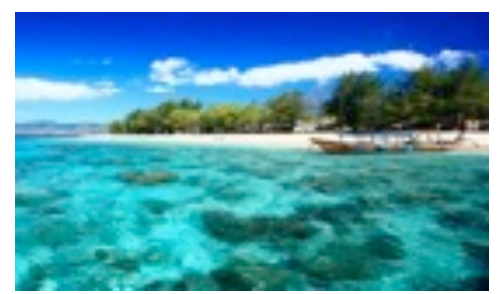

Gambar 4.2 Kondisi Eksisting Desa Gili Ketapang

Sumber: Dokumentasi Penelitian, Mei 2018

\section{KESIMPULAN DAN SARAN}

\subsection{KESIMPULAN}

Dari penelitian yang telah dilakukan diperolehlah beberapa simpulan yang dapat disampaikan sebagai hasil dari penelitian ini. Simpulan-Simpulan yang dapat disampaikan tersebut diantaranya adalah:

\section{a. Perencanaan (Planning)}

Akan diadakan perencanaan atraksi diving di zona laut pulau Gili Ketapang, pelestarian terumbu karang dan ikan akan dikembangkan semaksimal mungkin, dan akan ada penyewaan sepeda pancal. Selain itu pengelola dan peningkatan SDM akan melaksanakan kegiatan pembinaan dan pelatihan kepada staff, pihak pengelola masing-masing zona dan masyarakat sekitar dalam menjaga dan mengembangkan daya tarik wisata Pulau Gili Ketapang dan pemberian pelatihan dalam pembuatan sovenir lokal atau oleh-oleh khas dari Daya tarik wisata Gili Ketapang yang akan diproduksi oleh masyarakat lokal. Fasilitas pariwisata akan dibangun toilet yang lebih produktif dan efisien dalam pembuangan air bekas dan kualitas toilet baik bagi wisatawan adapun peningkatan kualitas layanan yang akan dilakukan ialah tentang hospitality yang baik, meningkatkan kualitas kebersihan dan kenyamanan wisatawan, serta akan mengadakan reward gift kepada staff terbaik di setiap bulannya. Serta Pemerintah dan Pengelola akan melakukan kegiatan promosi dan pemasaran Daya Tarik Wisata Pulau Gili Ketapang melalui media cetak dan elektronik, serta media online seiring kemajuan perkembangan teknologi dan informasi.

\section{b. Organisasi (Organizing)}

Pengorganisasian yang dilakukan pengelola terkait atraksi wisata di Daya Tarik Wisata Gili Ketapang sebagai berikut: Pengelola membuat dan mengatur jadwal atraksi wisata snorkling , Pengelola membuat dan mengatur jadwal penjemputan dan pengantaran wisatawan, dan Pengelola membuat papan pengumuman yang berisi aturan-aturan dari pemerintah, kepala desa terkait pelestarian ekosistem laut dan 
potensi alam, serta lingkungan. Selain itu membuat dan mengatur jadwal pembinaan serta pelatihan bagi pengelola masing-masing zona beserta staffnya dan masyarakat, selain itu pembuatan sovenir yang dilakukan oleh pengelola dan masyarakat desa serta menyediakan dan menata tempat dan sumber daya manusia. Pengelola membuat aturan mengenai penggunaan pakaian seragam dan juga dalam hal mempromosikan dan memasarkan daya tarik wisata Pulau Gili Ketapang yaitu melalui media sosial, seperti facebook, instagram, youtube, koran, dan interaksi.

\section{c. Penggerakan}

Pengelola melaksanakan kegiatan atraksi sesuai dengan apa yang sudah diatur dan telah direncanakan bersama staf dan permintan wisatawan, menyediakan usaha jasa foto yang kreatif dan inovatif untuk berfoto di atraksi snorkling dan bisa juga buat video, dan selain itu ada juga staf atau petugas yang bertugas mengantarkan wisatawan ke daya tarik wisata Goa Kucing yang berada di sebelah timur desa Gili Ketapang. Melaksanakan kegiatan pembinaan. Bersinergi dengan semua masyarakat, beserta staff nya . Di samping itu menunjukkan kerapian dan kesan yang baik kepada wisatawan, selain itumenggunakan hospitality yang baik. Serta melaksanakan kegiatan promosi dan pemasaran melalui media cetak dan media elektronik serta media sosial.

\section{d. Pengawasan (Controlling)}

Berkoordinasi dengan Kepala desa yang dalam hal pariwisata sekaligus sebagai Kelompok Sadar Wisata (Pokdarwis) melakukan pengawasan dan evaluasi terhadap pelaksanaan kegiatan dan melakukan evalusi terkait kenyamanan wisatawan dalam berkunjung serta staff serta keperihatian terhadap fasilitas semua yang ada. Selain itu Pengelola bersinegi dengan kepala desa mengadakan pengawasandan evaluasi terhadap kegiatan pembinaan mengenai informasi update yang dilaksanakan terhadap pengelola masing-masing zona dan masyarakat sekitar.
Dan juga promosi dan pemasaran antara lain. Di samping itu pengelola bersinergi dengan kepala desa mengadakan pengawasan dan evaluasi.

\subsection{Saran}

Adapun beberapa saran yang dapat disampaikan guna menjadi referensi beberapa pihak:

\section{Kepada Pemerintah}

Pemerintah sebagai fasilitator dalam hal ini diharapkan untuk memberikan pengarahan dan sosialisasi secara terpadu terkait sistem pengelolaan dan hendak ikut berpartisipasi penuh dalam upaya mempromosikan daya tarik wisata GiliKetapang sebagai tempat wisata yang memiliki potensi alam yang indah dan memiliki pengolalaan yang unggul dengan kualitas yang bagus. Selain itu pemerintah diharapkan dapat membantu lebih dalam pembangunan infrastruktur dan fasilitas wisata yang ada di daya tarik wisata Gili Ketapang.

\section{Pengelola}

Perlunya kesadaran dari pengelola Daya Tarik Wisata Gili Ketapang untuk lebih disiplin terhadap waktu bekerja dan selalu melakukan inovasi dan kreatifitas terhadap pengengembangan dan pengelolaan Daya Tarik Wisata Gili Ketapang.

\section{Masyarakat lokal}

Masyarakat Pulau Gili Ketapang diharapkan mampu menjaga potensi yang dimiliki saat ini, tanpa mengekploitasi berlebihan yang dapat menyebabkan kerusakan lingkungan, alih fungsi lahan terhadap pembangunan. Disamping itu masyarakat diharapkan juga berpartisipasi dalam membantu pengelolaan daya tarik wisata Gili Ketapang dengan mendukung program-program yang telah dirancang oleh pengelola dan pemerintah, serta masyarakat hendaknya dapat mejaga kebudayaannya.

\section{Akademisi}

Dalam penelitian ini belum mendalam dan holistik. Dalam penelitian selanjutnya diharapkan dapat melanjutkan penelitian dengan mengambil permasalahan mengenai 
strategi pengembangan daya tarik wisata

Gili Ketapang, Kecamatan Sumber Asih, Kabupaten Probolinggo

\section{DAFTAR PUSTAKA}

Anonim, 2009. Undang-Undang RI No.10 Tahun 2009 Tentang Kepariwisataan.

Ariyanto,.2005.Tentang Fasilitas Pariwisata

Butler.R.W, 1998."The Concept Of a Tourist Area Cycle of Evolution: Implications For Management of Resources". University of Western Ontario.

Gunn, Clare A. 1988. "Tourism Planning". Taylor \& Francis Publishing.

Pitana, I Gde dan I Ketut Surya Diarta. 2009. Pengantar Ilmu Pariwisata. Yogyakarta : ANDI

Rofiq, Zainur, 2013. Nilai Sosial dan Ekonomi pada Tradisi Ngalak Anak di Pulau Gili Ketapang Kabupaten Probolinggo.

Sugiyono. 2004. Metode Penelitian Kombinasi. Bandung: CV Alfabeta.

Widiarta, Nyoman, 2016. Pengelolaan Daya Tarik Wisata Pura Taman Ayun sebagai bagian dari Warisan Budaya Dunia.

Yoeti, Oka A, 1982. Pengantar Ilmu Pariwisata. Pengertian Pariwisata. Bandung. Angkasa.

Yulianie, Fatrisia. 2015. Partisipasi Dan Pemberdayaan Masyarakat Dalam Pengelolaan Daya Tarik Wisata "Rice Terrace" Ceking, Gianyar, Bali. Jurnal Master Pariwisata (JUMPA). Vol 2 No 1: Hal 165-184. 